\title{
The Presence and In Vivo Biosynthesis of Fragments of CPP (the C-Terminal Glycopeptide of the Rat Vasopressin Precursor) in the Hypothalamo-Neurohypophyseal System
}

\author{
MONICA A. SEGER AND J. PETER H. BURBACH \\ Rudolf Magnus Institute for Pharmacology, Medical Faculty \\ University of Utrecht, Vondellaan 6, 352l GD Utrecht, The Netherlands
}

Received 16 March 1987

\begin{abstract}
SEGER, M. A. AND J. P. H. BURBACH. The presence and in vivo biosynthesis of fragments of CPP (the C-terminal glycopeptide of the rat vasopressin precursor) in the hypothalamo-neurohypophyseal system. PEPTIDES 8(5) 757-762, 1987.-The existence and rate of formation of fragments of the 39-residue C-terminal glycopeptide of propressophysin $\left(\mathrm{CPP}_{1-39}\right)$ was investigated in the hypothalamo-neurohypophyseal system. Newly-prepared antisera to CPP were used to confirm the existence of smaller C-terminal fragments derived from $\mathrm{CPP}_{1-39}$. Radiolabelled fucose was injected into rats in vivo into the area of the supraoptic nucleus, and the labelled peptides formed in the neurohypophysis were examined at various time intervals up to five weeks after the injection. The products derived from the neurohypophyseal hormone precursors were separated by high-performance liquid chromatography. The level of the major immunoreactive C-terminal fragment ( $\left.\mathrm{CPP}_{22-39}\right)$ was constant and represented about $5 \%$ of the intact $\mathrm{CPP}_{1-39}$ in the neurohypophysis. The appearance of newly-synthesized $\mathrm{N}$-terminal fragment of $\mathrm{CPP}_{1-39}$ occurred only after 3 or 4 days. This fucose labelled fragment increased slowly thereafter until it reached the same level as the CPP C-terminal fragment immunoreactivity between 21 and 28 days after injection. The results suggest that $\mathrm{CPP}_{1-39}$ is extremely stable in the hypothalamo-neurohypophyseal neurons, and that the cleavage at $\mathrm{Arg}_{21}-\mathrm{Leu}_{22}$ is a delayed proteolytic event in the magnocellular neurons of the SON.
\end{abstract}

Propressophysin C-terminal glycopeptide Biosynthesis Magnocellular neurons

Hypothalamo-neurohypophyseal system

SINCE the first suggestion of the existence of a precursor for vasopressin in 1964 [22], the biosynthesis of the neurohypophyseal hormone precursors has received much attention. The general structures of propressophysin and prooxyphysin were discovered by in vivo injection of ${ }^{35} \mathrm{~S}$ cysteine into the SON [20]. These studies suggested the existence of two distinct neurophysins (NPI and NPII) cosynthesized in the precursor proteins with oxytocin (OT) and vasopressin (VP) respectively, and the existence of a unique glycopeptide in propressophysin. In both precursors, OT or VP are located at the extreme $\mathrm{N}$-terminus and are followed by their respective neurophysins beginning in position 13 . The location of the glycopeptide at the C-terminus of the vasopressin precursor (and hence the name CPP for C-terminal peptide of propressophysin) was confirmed by the cDNA sequence analysis of the RNAs encoding the two precursors from the bovine hypothalamus $[12,13]$.

An in vivo biosynthesis approach has generally been used to study several aspects of neurohypophyseal hormone biochemistry $[9,21,27,28,30]$ but the vasopressinassociated glycopeptide has been largely ignored due to its

\section{ABBREVIATIONS}

$\begin{array}{ll}\text { CPP } & \begin{array}{c}\text { carboxyl-terminal peptide of propressophysin, } \\ \text { i.e., residues 108-147 of the precursor }\end{array} \\ \text { SON } & \text { supraoptic nucleus } \\ \text { HPLC } & \text { high-performance liquid chromatography } \\ \text { NIL } & \text { neurointermediate lobe of the pituitary }\end{array}$

apparent lack of biological function. However, its absence from prooxyphysin and the high level of conservation of the $\mathrm{CPP}_{1-39}$ sequence between species [24-26] suggest that it may have an important role in vasopressinergic neurons.

Biosynthesis experiments with tritiated fucose and glucosamine [21] have suggested that CPP is cleaved from propressophysin as the full 39 residue peptide. However, the finding of smaller peptides in the neurohypophysis apparently derived from $\mathrm{CPP}_{1-39}$ has led to suggestions that CPP may be further cleaved in the pituitary. CPP was originally encountered as a 17-amino acid fragment isolated from porcine pituitaries [10]. Subsequently, other investigators iso- 
lated peptides having the sequence of CPP 1 to 10 and 1 to 19 in acid acetone extracts of the pituitary [26], and acetic acid extracts of rat neurointermediate lobes (NIL) were found to contain fragments derived from the C-terminal glycopeptide [3]. These peptides included the $\mathrm{N}$-terminal fragments $\mathrm{CPP}_{1-20}$ and $\mathrm{CPP}_{1-19}$, and the C-terminal fragments $\mathrm{CPP}_{22-39}$ and $\mathrm{CPP}_{22-37}$.

The aim of the present study was to investigate the possible cleavage of $\mathrm{CPP}_{1-39}$ into these previously-identified fragments of CPP and to study the time course of cleavage in the magnocellular neurons projecting to the pituitary gland. The in vivo biosynthesis of $\mathrm{CPP}_{1-39}$ and its $\mathrm{N}$-terminal fragment(s) following the injection of a radiolabelled amino acid or sugar residue into the SON was combined with determinations of peptide levels of C-terminal forms of CPP in the NIL by radioimmunoassay. The levels of C-terminal fragments of CPP and the other biosynthetic derivatives of the two neurohypophyseal hormone precursors were compared with the amount of radiolabelled products after HPLC separation of the NIL extracts. The results indicate that low levels of CPP fragments exist in the pituitary gland which are formed as a late event in propressophysin maturation.

\section{METHOD}

\section{Material}

The peptide corresponding to the sequence of rat $\mathrm{CPP}_{22-38}$ was synthesized by Drs. H. M. Greven and J. W. van Nispen (Organon International B.V., Oss, The Netherlands). The CPP fragment corresponding to the sequence 22-37 was prepared by digestion of the synthetic peptide with carboxypeptidase A (Sigma, St. Louis, MO). Peptide maps of radiolabelled $\mathrm{CPP}_{1-39}$ and its $\mathrm{N}$-terminal fragment were made using trypsin (Serva Feinbiochemica, Heidelberg, FRG). Acetonitrile (HPLC grade) was purchased from J. T. Baker Chemicals B.V. (Deventer, NL), and trifluoroacetic acid (HPLC grade) was bought from Merck (Schuchardt, FRG). The HPLC system was from Water Associates (Milford, MA) and it consisted of two pumps (Model 6000A), a gradient programmer (Model 660), a universal injector (Model U6K) and a variable wavelength UV-monitor (Model 450). The reversed-phase Vydac $201 \mathrm{TP}(5 \mu \mathrm{m})$ material was packed into a Chrom-Sep ${ }^{\mathrm{TM}}$ column (Chrompack Int. B.V., Middelburg, NL) which had the following dimensions: $100 \times 3.0 \mathrm{~mm}$ ID. The radiolabelled compounds were purchased from the Radiochemical Centre, Amersham, UK. Iodogen was obtained from the Pierce Chemical Co. (Chicago, IL), and bovine serum albumin (BSA) was from Sigma.

In Vivo Injection of Radiolabelled Substances and Peptide Extraction

Male Wistar rats (between 150 and $170 \mathrm{~g}$ ) were anaesthetized with Fentanyl ( $1 \mu \mathrm{g} / \mathrm{g}$ body weight) and placed in a stereotaxic apparatus with $0^{\circ}$ head position. $12.5 \mu \mathrm{Ci}$ of ${ }^{3} \mathrm{H}$ fucose $(45 \mathrm{Ci} / \mathrm{mmol})$ or ${ }^{3} \mathrm{H}$-tyrosine $(115 \mathrm{Ci} / \mathrm{mmol})$ were injected bilaterally in $1 \mu \mathrm{l}$ of sterile $0.9 \% \mathrm{NaCl}$ solution dorsolateral to the SON (A: $-0.5, \mathrm{~L}: 2.5, \mathrm{~V}: 8.6$ ) over one minute. After waiting for one minute to prevent reflux into the syringe, the animal was allowed to recover and was maintained at standard light and temperature conditions and provided with food and tap water ad lib. The rats were decapitated after various time intervals and the neurointermediate lobe of the pituitary was removed within 30 seconds and homogenized immediately in $200 \mu$ l of ice-cold $0.1 \mathrm{~N}$ $\mathrm{HCl}$ containing $5 \%$ formic acid, $1 \%$ trifluoroacetic acid
(TFA) and $1 \% \mathrm{NaCl}$ [1]. After centrifugation for 10 minutes at $5000 \mathrm{rpm}$ at $4^{\circ} \mathrm{C}$, the supernatant was stored at $-20^{\circ} \mathrm{C}$ until HPLC analysis. The brains were examined to verify the site of injection.

\section{HPLC Analysis}

A reversed-phase HPLC system was used to separate the peptides in the NIL extracts with a solvent system of acetonitrile (MeCN) containing 0.1\% TFA [2]. The peptides were eluted from the column with a linear gradient of 8 to $48 \% \mathrm{MeCN}$ over one hour with a flow rate of $1 \mathrm{ml} / \mathrm{min}$ and one-minute fractions were collected in counting vials. The amount of VP, OT, NPI, NPII and CPP ${ }_{1-39}$ was estimated by ultraviolet absorbance at $210 \mathrm{~nm}$. Aliquots of the fractions were dried in a Speed-Vac concentrator (Savant, Hicksville, NY) for radioimmunoassay, and $100 \mu \mathrm{l}$ aliquots of the fractions were counted by liquid scintillation. The identity of the peptides was established by comparison of the elution positions with a previous study [2] and by co-elution of synthetic standard peptides when available.

\section{Enzymatic Digests}

$\mathrm{CPP}_{22-39}$ was incubated for $1 \mathrm{hr}$ with carboxypeptidase $\mathrm{A}$ in $0.15 \mathrm{M}$ Tris $\mathrm{HCl}$ buffer, $\mathrm{pH} 8$ at room temperature, with a molar ratio of 200:1. The trypsin digests were carried out in $0.2 \mathrm{M}$ sodium bicarbonate buffer, $\mathrm{pH} 8.2$, for $4 \mathrm{hr}$ with a $50: 1$ ratio of substrate to enzyme $(w / w)$ at $37^{\circ} \mathrm{C}$. The enzymatic reactions were stopped by freezing the samples and the reaction products were separated by HPLC.

\section{Antibody Formation}

$\mathrm{CPP}_{22-39}$ was conjugated to thyroglobulin with watersoluble dicarbodiimide and stirred for 24 hours at $\mathrm{pH} 7.4$ at $4^{\circ} \mathrm{C}$. The mixture was then dialyzed against distilled water for $48 \mathrm{hr}$, and an aliquot was analyzed by HPLC to determine that approximately $50 \%$ was conjugated. The material was then dissolved in $0.9 \% \mathrm{NaCl}$ and Freund's complete adjuvant (DIFCO Laboratories, Detroit, MI) and emulsified. The rabbits received either intracutaneous (C) or intramuscular (M) injections. Venous blood was drawn from the ear.

\section{Radioimmunoassay}

Synthetic $\mathrm{CPP}_{22-39}$ was iodinated by the iodogen method as described previously [23]. Duplicates of the standard curve (dilutions of $\mathrm{CPP}_{22-39}$ from $5 \mathrm{pg}$ to $5 \mathrm{ng}$ ) were prepared in $125 \mathrm{mM}$ phosphate buffered saline (PBS) containing BSA $(0.25 \%)$ and Triton $X-100(0.1 \%)$. The samples were reconstituted in the same buffer. Aliquots of $100 \mu$ l of sample or standard, $50 \mu \mathrm{l}$ of antibody (diluted 1:300 or 1:25 for $M$ and $\mathrm{C}$, respectively) and $50 \mu \mathrm{l}$ of tracer $(8-10,000 \mathrm{cpm})$ were incubated for $16 \mathrm{hr}$ at $4^{\circ} \mathrm{C}$. The assay was ended by the addition of $50 \mu \mathrm{l}$ of horse serum and $1 \mathrm{ml}$ of polyethylene glycol in $11 \mathrm{mM}$ PBS containing $0.5 \%$ Tween-20 (Merck). After vortexing, the samples were centrifuged at $3000 \mathrm{rpm}$ at $4^{\circ} \mathrm{C}$ for 10 minutes to separate the bound and free radioactivity. The supernatants were discarded and the pellets were counted in a gamma counter.

\section{Cross-Reactivity of the Antisera}

Characterization of the antisera was done using synthetic and endogenous peptides (see Fig. 1). The $C$ antisenum recognized the C-terminus of CPP and had $38.1 \%$ cross- 


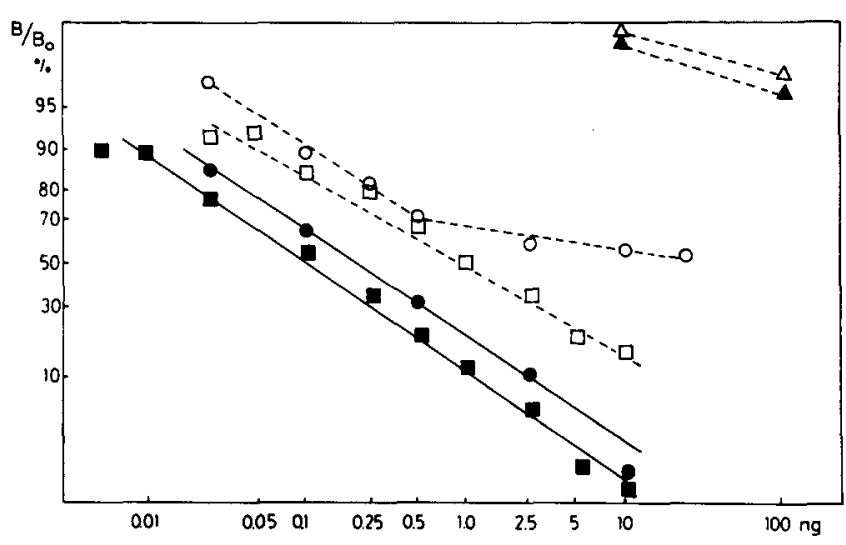

FIG. 1. Representative standard curves of CPP RIAs with A: antiserum $C$ (dilution 1:100) shown by the dotted lines; and $B$ : antiserum $M$ (dilution 1:1200) shown by the solid lines and crossreactivity of various peptides. $\square$ and $\square=$ rat $\mathrm{CPP}_{22-39}, O$ and $\Theta=$ rat $\mathrm{CPP}_{22-37}, \Delta=$ human $\mathrm{CPP}$ and $\triangle=$ ovine CPP.

reactivity with purified endogenous rat $\mathrm{CPP}_{1-39}$. No significant displacement of tracer was found with VP, OT, NPI or NPII, and the cross-reactivity with $\mathrm{CPP}_{22-37}$ was only $3.6 \%$ The $\mathrm{M}$ antiserum was directed to the middle portion of $\mathrm{CPP}_{22-39}$ and cross-reacted with rat $\mathrm{CPP}_{1-39}(21.3 \%)$ and with $\mathrm{CPP}_{22-37}(60 \%)$. The cross-reactivity with ovine CPP was $0.002 \%$ and $0 \%$ (for $M$ and $C$, respectively) and $0.006 \%$ and $0.005 \%$ with human CPP (for $M$ and $C$, respectively). The cross-reactivity of $M$ with the other neural lobe peptides was less than $0 \%$. The sensitivity of the assay using $M$ was $10 \mathrm{pg}$, and $50 \mathrm{pg}$ using $C$. The $B_{30}$ was $105 \mathrm{pg}$ (for $\mathrm{M}$ ) and $600 \mathrm{pg}$ (for C). Both antisera were used for the quantitation of peptides. The location of label on the C-terminal tyrosine residue may be responsible for the low sensitivity obtained with the $\mathrm{C}$ antiserum, since sensitive immunocytochemical staining was observed using this antiserum at a dilution of 1:1000 (F. F. W. van Leeuwen, personal communication).

\section{RESULTS}

\section{CPP-Immunoreactive Forms}

The peptides derived from the two neurohypophyseal hormone precursors were well separated by the chromatographic system used. Figure 2a shows a characteristic HPLC profile and the elution positions of the CPP-immunoreactive peptides are shown in Fig. 2c. The major C-terminal fragment of CPP was found at the elution position of $\mathrm{CPP}_{22-39}$ (fraction 19). This peptide cross-reacted equally well with the $M$ and $C$ antisera. A minor fragment, detected only with the $\mathrm{M}$ antiserum, resembled $\mathrm{CPP}_{22-37}$ in its elution position (fractions 15 and 16). However, with the available methods, the exact nature of the $\mathrm{N}$-terminal residue of these fragments was not determined.

The total amount of CPP C-terminal immunoreactive fragments detected in the posterior pituitary was $22.3 \pm 2.4$ $n g /$ lobe $(n=10)$. This represents about $5 \%$ of the total CPP immunoreactivity. The proportion of fragments is less than that reported for a previous isolation and characterization of CPP fragments from acetic acid extracts of the rat NIL [3] which contained approximately $20 \%$ the molar ratio of fragments.
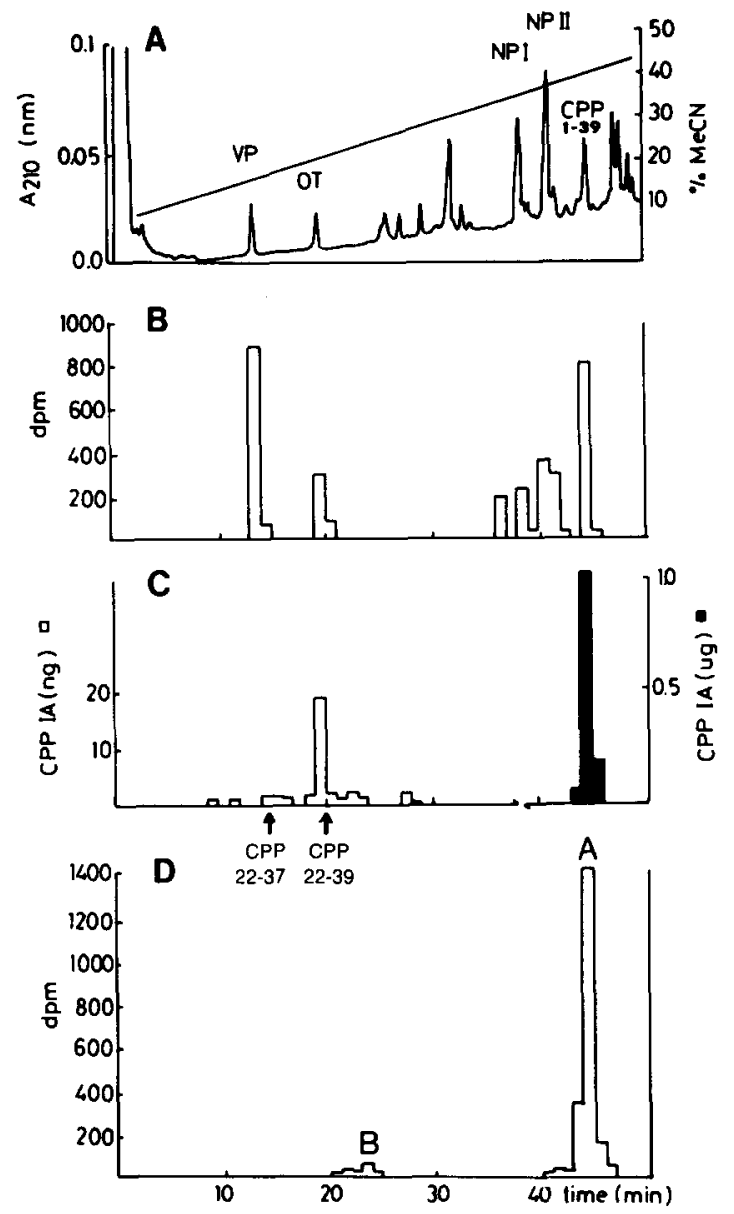

FIG. 2. HPLC profile of peptides extracted from a single rat neurointermediate pituitary gland five weeks after injection of 25 $\mu \mathrm{Ci}$ of ${ }^{3} \mathrm{H}$-tyrosine in the SON. a: The extract was analyzed by HPLC using a linear gradient from 8 to $48 \%$ MeCN containing $0.1 \%$ TFA over 1 hour at a flow rate of $1 \mathrm{ml} / \mathrm{min}$ with collection of fractions of $1 \mathrm{ml}$. b: The amount of radioactivity in each fraction was determined by liquid scintillation counting of one-tenth (i.e., $100 \mu \mathrm{l}$ ) of each sample. c: The immunoreactivity of each fraction was determined by RIA for CPP using antiserum $M$ as described in the Method section. d: Radioactivity in each fraction after a similar experiment five weeks after injection of $25 \mu \mathrm{Ci}$ of ${ }^{3} \mathrm{H}$-fucose. A is intact $\mathrm{CPP}_{1-39}$ and $\mathrm{B}$ represents ${ }^{3} \mathrm{H}$-fucose labelled fragment (see text). The elution positions of synthetic peptides is shown in panel $C$, and the identities of the other neural lobe peptides which are shown in panel $A$ have been described in [2].

\section{In Vivo Biosynthesis}

The injection of a tritiated amino acid was used to assess the overall new synthesis of peptides derived from propressophysin and prooxyphysin. A single tyrosine is present in each of the principal products of the two precursors and thus equivalent amounts of radioactivity are expected for each peptide. This was indeed the case for VP, NPII and CPP $_{1-39}$, and also for OT and NPI as shown in Fig. $2 \mathrm{~b}$. Consistently more radioactivity was incorporated into the VP precursor than in the OT precursor, suggesting that the injection site was in an area containing more VP cells than OT cells (i.e., the rostral and lateral parts of the SON). The level of ${ }^{3} \mathrm{H}$-tyrosine incorporation decreased slowly over time after its peak at 7 days (results not shown), whereas the 


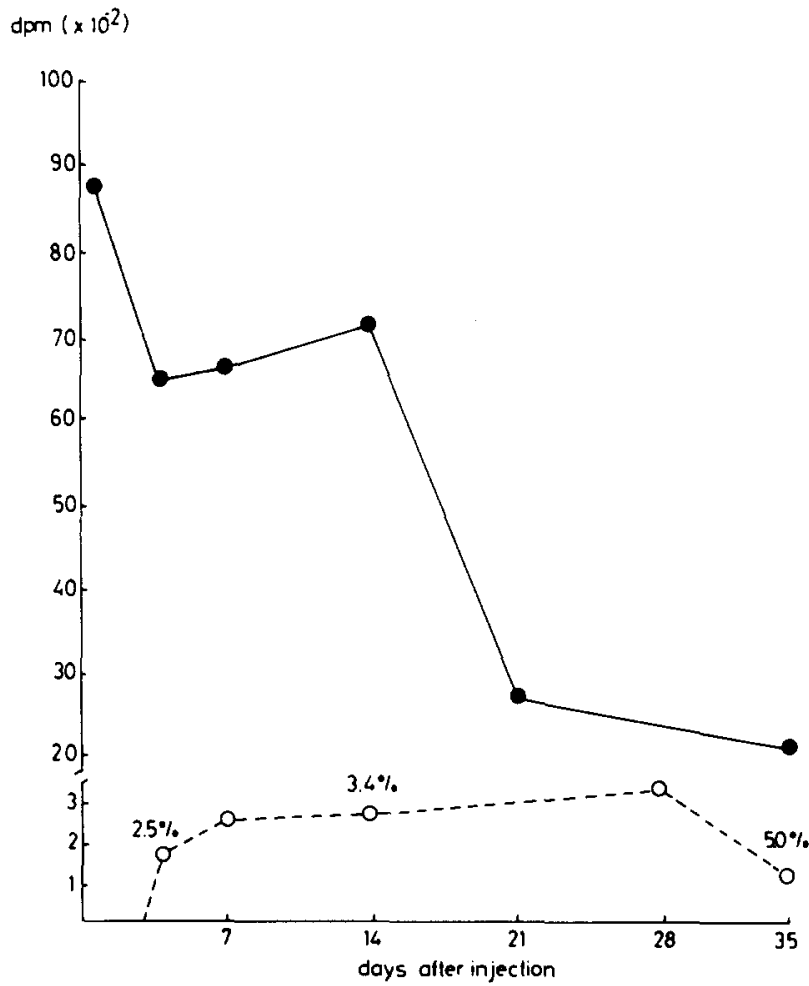

FIG. 3. Time course of ${ }^{3} \mathrm{H}$-fucose incorporation and CPP fragment formation. The amount of radioactivity incorporated into intact $\mathrm{CPP}_{1-39}$ (Peak A in Fig. 2d, solid circles and solid line) and into the $\mathrm{N}$-terminal CPP fragment (Peak B in Fig. 2d, open circles and dotted line), as determined by HPLC analysis, is plotted against the time (in days) after injection of ${ }^{3} \mathrm{H}$-fucose into the SON of the rat. The percent of counts present in the $\mathbf{N}$-terminal fragment compared to the intact $\mathrm{CPP}_{1-39}$ is also indicated for several time points.

tissue levels of peptides, as estimated from the UV absorbance profiles after HPLC analysis, remained constant.

The incorporation of fucose, as shown in Fig. 2d, was much more efficient. The pattern of incorporation was simple and highly reproducible. For the time points which were done in duplicate (results not shown), the variation was less than 15\%. After 24 hours, the highest amount of radioactivity was present in the form of CPP $_{1-39}$ in the neural lobe, and it remained at approximately the same level for 2 weeks (see Fig. 3). A single peak of ${ }^{3} \mathrm{H}$-fucose containing material (peak A) which co-eluted with $\mathrm{CPP}_{1-39}$ was found during the first three days after injection. At day 4, 2.7\% of the label was found in a form resembling $\mathrm{CPP}_{1-20}$ or $\mathrm{CPP}_{1-19}$ (peak $\mathrm{B}$ ) in elution position. Tryptic maps of the ${ }^{3} \mathrm{H}$-fucose labelled material in peaks $A$ and $B$ were made in parallel to verify that the peptide in peak $B$ was indeed derived from $C P_{1-39}$. The analysis of both digests in serial HPLC runs showed that both contained a single labelled fragment eluting at $14 \%$ $\mathrm{MeCN}$ which probably represents $\mathrm{CPP}_{1-15}$ or $\mathrm{CPP}_{3-15}$, thus substantiating the conclusion that the biosynthesized peptide was derived from $\mathrm{CPP}_{1-39}$.

\section{DISCUSSION}

The SON was chosen as the site of injection since the magnocellular neurons contained within this nucleus are directed solely to the neurohypophysis and central projections from the SON are virtually absent [6]. Thus it is a suitable system with which to study only the peripherally directed vasopressinergic neurons. Moreover, the area is easily accessible without causing extensive damage in the brain. The constant level of posterior pituitary peptides found at various times after injection indicated that the neural system was intact and that there was no change in peptide production and/or release due to the operation. Furthermore, the level of C-terminal fragment immunoreactivity was constant over time suggesting, along with the estimated contents of the other neural lobe peptides, that there is no change in the processing or release of neurohypophyseal peptides.

The glycosylation of CPP is highly conserved and the $\mathrm{N}$-linked carbohydrate moiety is attached to asparagine residue 6 . The carbohydrate structure was found to contain 9 to 10 sugar residues including 4 glucosamine, 3 mannose, 1 galactose and 1 fucose [10]. Recently it was found that fucose is attached to the first $\mathrm{N}$-acetyl glucosamine in the core of the sugar structure and that the sugar is very stable under the extraction conditions used for this study [11]. Microheterogeneity was only found for the terminal galactose residues at the non-reducing end of the molecule. Thus fucose is a useful sugar residue for biosynthetic labelling of the $\mathrm{N}$-terminus of CPP.

The combined use of in vivo labelling with tritiated fucose and radioimmunoassays has provided evidence for the existence of CPP fragments in the posterior pituitary synthesized in the SON. N-Terminal fragment was detected by the presence of another form of ${ }^{3} \mathrm{H}$-fucose labelled peptide several days after injection of the radiolabelled sugar into the hypothalamic neurons. That this newly-synthesized peptide is related to CPP was suggested by the identity of labelled peptide formed in the tryptic digest of peak $B$ and that of $\mathrm{CPP}_{1-39}$. The amount of labelled $\mathrm{N}$-terminal fragment increased slowly to reach a maximum of about $5 \%$ after 5 weeks which equalled the level of C-terminal fragment immunoreactivity found in the tissue. The amount (up to 5\%) was less than the recovery of the CPP fragments purified from large batches of NIL extracted by a different procedure [3]. However, the nature of the fragments formed in vivo is similar to those found in these previous extracts of rat pituitaries. The results point to a primary cleavage site after $\operatorname{Arg}_{20}$.

The amount of N-terminal CPP fragment labelled with fucose was smaller than that reported in the guinea pig [14] but the predicted half-life of the glycopeptide agrees with the present study. Our studies (results not shown) and those of other groups have shown that newly-synthesized CPP can be found in the pituitary as early as 6 hours after injection. It has been estimated that the rate of transport of the neurohypophyseal hormones is 2 to $3 \mathrm{~mm} / \mathrm{hr}$ [17] and thus newly-synthesized material could be transported in the axons very rapidly. The finding that cleavage of $\mathrm{CPP}_{1-39}$ takes several days suggests that the products must be retained in the granules for quite some time before release. It could be that in the present experiments the incorporation of label was continuing for several days after a single injection which may explain the apparent plateau obtained between 1 and 14 days after injection. That this is not due to animal variation is indicated by the high degree of reproducibility.

When compared to the time course of cleavage of other prohormone products the proposed processing of $\mathrm{CPP}_{1-39}$ is slow indeed. For example, the C-terminal cleavage of endorphin as determined by pulse-chase studies in NILs incubated in vitro $[15,16]$ is 18 to 24 hours. The present results 
suggest that the cleavage, occurring presumably after $\operatorname{Arg}_{20}$, is a late event in the intragranular processing of pressophysin. The site of cleavage is similar to that which is used for the cleavage of $\mathrm{CPP}_{1-39}$ from neurophysin. It is becoming evident that many putative processing enzymes require only a single basic residue for cleavage, such as the bag-cell cleaving enzyme found in Aplysia [24], the kallikreins [19] and the novel POMC-processing enzyme identified in porcine pituitary extracts [5]. The cleavage site in $\mathrm{CPP}_{1-39}$ may be recognized by the same enzyme as that involved in the cleavage of the VP precursor, but the conformation of the amino acids around this site may not be as favourable, preventing rapid cleavage.

The in vivo biosynthesis experiments indicate that in the magnocellular vasopressinergic neurons originating in the SON, CPP ${ }_{1-39}$ is cleaved only to a small extent into smaller fragments. Preliminary studies have revealed that similar levels of radiolabelled CPP fragments are found in the NIL when label is injected in the paraventricular nucleus, indicating that this degree of CPP processing is a general property of magnocellular VP neurons. However, in the parvocellular neurons which project into the brain, a different degree of CPP cleavage may occur. The level of C-terminal CPP fragments appears to be greater in the pineal gland, septum and superior cervical ganglion (unpublished observations). A previous study has suggested that the cleavage of VP may be more extensive in the brain and lead to the formation of behaviourally-active substances [4]. There are several other examples of tissue-specific hormone processing, such as pro-opiomelanocortin [8], somatostatin [18] and proglucagon [7]. Further work will be focussed on quantitating and examining the nature of the CPP fragments found in other areas of the brain which may contain the terminals of vasopressinergic neurons in order to investigate the possibility of differential cleavage of $\mathrm{CPP}_{1-39}$.

\section{ACKNOWLEDGEMENTS}

Monica Seger is supported by a Fellowship from the Medical Research Council of Canada. The authors are grateful to Dr. F. van Leeuwen for testing the antisera by immunocytochemistry, and to Ineke Koekkoek and Willeke Logtenberg for iodinating CPP. We thank Dr. N. G. Seidah for the gift of purified ovine and human CPP.

\section{REFERENCES}

1. Bennett, H. P. J., C. A. Browne and S. Solomon. Purification of the two major forms of rat corticotropin using only reversedphase liquid chromatography. Biochemistry 20: 4530-4538, 1981.

2. Browne, C. A., H. P. J. Bennett and S. Solomon. The isolation of peptides by high-performance liquid chromatography using predicted elution position. Anal Biochem 254: 201-208, 1981.

3. Burbach, J. P. H., N. Seidah and M. Chrétien. Isolation and primary structure of novel neurointermediate pituitary peptides derived from the C-terminal of the rat vasopressin-neurophysin precursor (propressophysin). Eur J Biochem 156: 137-142, 1984.

4. Burbach, J. P. H., X.-C. Wang, J. Ten Haaf and D. de Wied. Substances resembling $\mathrm{C}$-terminal vasopressin fragments are present in the brain but not in the pituitary gland. Brain Res 306 : 384-387, 1984.

5. Cromlish, J., N. Seidah and M. Chrétien. A novel serine protease (IRCM-serine protease $\mathrm{E}$ ) from porcine neurointermediate and anterior pituitary lobes. J Biol Chem 261: 1085010858, 1986.

6. de Vries, G. J., R. M. Buijs, F. W. van Leeuwen, A. R. Caffé and D. F. Swaab. The vasopressinergic innervation of the brain in normal and castrated rats. $J$ Comp Neurol 233: 236-254, 1987.

7. Drucker, D. J., S. Mojsov and J. F. Habener. Cell-specific post-translational processing of preproglucagon expressed from a metallotheionein-glucagon fusion gene. I Biol Chem 261: 9637-9643, 1986.

8. Eipper, B. A. and R. E. Mains. Structure and biosynthesis of proadrenocorticotropin/endorphin and related peptides. Endocr Rev 1: 1-27, 1980.

9. Franco-Bourland, R. E. and J. D. Fernstrom. In vivo biosynthesis of $L-\left[{ }^{35} S\right]$ Cys-Arginine vasopressin and oxytocin and somatostatin: rapid estimation using reversed-phase HPLC. Endocrinology 109: 1097-1106, 1981.

10. Holwerda, D. A. A glycopeptide from the posterior lobe of pig pituitaries. 2. Primary structure. Eur J Biochem 28: 340-346, 1972.

11. Lambert, G. Ph.D. Thesis, McGill University, Montreal, Canada, 1987.

12. Land, H., G. Schutz, H. Schmale and D. Richter. Nucleotide sequence of cloned cDNA encoding bovine arginine vasopressin neurophysin II precursor. Nature 295: 299-303, 1982.
13. Land, H., M. Grez, S. Ruppert, H. Schmale, M. Reihbein, D. Richter and G. Schutz. Deduced amino acid sequence from bovine oxytocin-neurophysin I precursor cDNA. Nature 302: 342-344, 1983.

14. Lawson, L. J. and R. W. Swann. Turnover of the vasopressin glycopeptide in the rat posterior pituitary gland. $J$ Endocrinol 102, Suppl, Abstr 48 of the IXth Anglo-Dutch Endocrine Meeting, 1984.

15. Liotta, A. S., H. Yamaguchi and D. T. Krieger. Biosynthesis and release of $\beta$-endorphin, $\mathrm{N}$-acetyl $\beta$-endorphin, $\beta$-endorphin ${ }_{1-27}$, and $\mathrm{N}$-acetyl $\beta$-endorphin - $_{1-27}$-like peptides by rat pituitary neurointermediate lobes: $\beta$-endorphin is not further processed by anterior lobe. $J$ Neurosci 1: 585-595, 1981.

16. Mains, R. E. and B. A. Eipper. Synthesis and secretion of corticotropins, melanotropins and endorphins by rat intermediate pituitary cells. J Biol Chem 254: 7885-7894, 1974.

17. Norstrom, A. and J. Sjostrand. Axonal transport of proteins in the hypothalamo-neurohypophyseal system of the rat. $J$ Neurochem 18: 29, 1971.

18. Patel, Y. C., H. H. Zingg, D. Fitz-Patrick and C. B. Srikant Somatostatin: Some aspects of its physiology and pathophysiology. In: Gut Hormones, edited by S. R. Bloom and J. M. Pollack. London: Churchill Livingstone, 1981, pp. 330-349.

19. Roberts, J. L. and D. Pritchett. Does the kallikrein-like enzyme gene family code for a group of peptide hormone-processing enzymes? Trends Neurosci 7: 105-107, 1984.

20. Russell, J. T., M. J. Brownstein and H. Gainer. Biosynthesis of vasopressin, oxytocin and neurophysins: isolation and characterization of two common precursors (propressophysin and prooxyphysin). Endocrinology 107: 1880-1890, 1980.

21. Russell, J. T., M. J. Brownstein and H. Gainer. [ $\left.{ }^{35} \mathrm{~S}\right]$ Cysteine labeled peptides transported to the neurohypophyses of adrenalectomized, lactating and Brattleboro rats. Brain Res 201: 227-234, 1980.

22. Sachs, $H$. and $Y$. Takabatake. Evidence for a precursor in vasopressin biosynthesis. Endocrinology 75: 943-950, 1964.

23. Salacinsky, P., C. McLean, J. Sykes, V. Clemens-Jones and P. J. Lowry. Iodination of proteins, glycoproteins and peptides using a solid-phase oxidizing agent, 1,3,4,6-tetrachloro-3 $\alpha, 6 \alpha$ diphenyl glucoril (Iodogen). Anal Biochem 117: 136-146, 1981. 
24. Schmale, H., S. Heinsohn and D. Richter. Structural organization of the rat gene for arginine-vasopressin neurophysin precursor. EMBO J 2: 763-767, 1983.

25. Seidah, N. G., S. Benjannet and M. Chrétien. The complete sequence of a novel human pituitary glycopeptide homologous to pig posterior pituitary glycopeptide. Biochem Biophys Res Commun 100: 901-902, 1981.

26. Smyth, D. G. and D. E. Massey. A new glycopeptide in pig, ox and sheep pituitary. Biochem Biophys Res Commun 87: 1006$1010,1979$.

27. Swann, R. W., C. B. Gonzalez, S. Birkett and B. Pickering. Precursors in the biosynthesis of vasopressin and oxytocin in the rat. Biochem $J$ 208: 339-349, 1982.
28. Swann, R. W., C. B. Gonzalez, S. D. Birkett and B. T. Pickering. Harbingers and hormones. Inter-relationships of rat neurohypophyseal hormone precursors in vivo. Prog Brain Res 60: 235-239, 1983.

29. Wallace, E. F., E. Weber, J. D. Barchas and C. J. Evans. A putative processing enzyme from Aplysia that cleaves dynorphin $\mathrm{A}$ at the single arginine residue. Biochem Biophys Res Commun 119: 415, 1984.

30. White, J. D., J. E. Krause and J. F. McKelvy. In vivo biosynthesis and transport of oxytocin, vasopressin, and neurophysins to the posterior pituitary and nucleus of the solitary tract. $J$ Neurosci 4: 1262-1270, 1984. 